\title{
PREVALENCE AND FACTORS ASSOCIATED WITH INJURIES IN RECREATIONAL RUNNERS: A CROSS-SECTIONAL STUDY
}

\author{
PREVALÊNCIA EFATORES ASSOCIADOS ÀS LESÕES EM CORREDORES AMADORES:
}

ARTIGO ORIGINAL Artículo Original

\section{PREVALENCIA Y FACTORES ASOCIADOS A LESIONES EN CORREDORES AFICIONADOS: UNESTUDIO TRANSVERSAL}

\author{
Maria Eduarda Ferreira Costa' (ID \\ (Physiotherapist) \\ Jader Barbosa Fonseca² (iD \\ (Physiotherapist) \\ Ana Izabela Sobral de Oliveira ${ }^{3}$ (ID) \\ (Physiotherapist) \\ Kryslly Danielle de Amorim Cabral ${ }^{1}$ (D) \\ (Physiotherapist) \\ Maria das Graças Rodrigues de (ID \\ Araújo ${ }^{4}$ (Physiotherapist) \\ Ana Paula de Lima Ferreira ${ }^{4}$ (ID \\ (Physiotherapist) \\ 1. Universidade Federal de \\ Pernambuco (UFPE), Recife, \\ PE, Brazil. \\ 2. Universidade Federal de \\ Pernambuco (UFPE), Postgraduate \\ Program in Physiotherapy, Recife, \\ PE, Brazil. \\ 3. Universidade Federal de \\ Pernambuco (UFPE), Postgraduate \\ Program in Neurosciences, Recife, \\ PE, Brazil. \\ 4. Universidade Federal de \\ Pernambuco (UFPE), Physiotherapy
} Department, Recife, PE, Brazil.

\section{Correspondence:}

Ana Paula de Lima Ferreira.

Universidade Federal de

Pernambuco (UFPE). Centro de

Ciências da Saúde. Departamento

de Fisioterapia. Av. Jornalista

Aníbal Fernandes, s/n, Cidade

Universitária, Recife, PE, Brazil.

50740-521.apllima@yahoo.com.br

\begin{abstract}
Introduction: The increased number of people who choose running as a form of exercise has been associated with a higher prevalence of musculoskeletal injuries. Objectives: To determine the prevalence and the factors that could be correlated with injuries among amateur runners in Recife, in the State of Pernambuco (PE), Brazil. Methods: An observational, cross-sectional study, in which 300 (three hundred) amateur runners answered a social demographic questionnaire, as well as questions about training characteristics, footstrike and landing pattern, and history of running injuries. The data were analyzed by descriptive statistics, the student- $t$ test to compare means, and the Chi-squared to compare prevalences. Results: The prevalence of injuries amongst runners in Recife-PE was $58.5 \%$ ( $n=175)$, the knee being the most commonly injured site (37.3\%). In both groups - runners with and without injuries - there was a higher number of male runners, with $72.4 \%$ and $72.6 \%$ respectively. There was no difference in relation to the weekly frequency of running between the groups $(p<0.63)$. However, runners with a history of injuries ran around $7 \mathrm{kmh}$ a week more than the runners without injuries $(\mathrm{p}<0.03)$. A neutral footstrike ( $\mathrm{F}=0.87 ; \mathrm{p}=0.99)$ and hindfoot landing $(\mathrm{F}=4.13 ; \mathrm{p}=0.90)$ were the most reported running patterns in both groups. It was found that wear was the main criterion used for changing running shoes in both groups $(F=8.35, p=0.4)$. Conclusion: There was a high prevalence of musculoskeletal injuries among amateur runners in Recife-PE. Among the factors associated with the injuries, one variable was significant: a higher weekly volume of training. Level of evidence Il; Study type: Cross-sectional study.
\end{abstract}

Keywords: Running; Epidemiology; Injuries.

\section{RESUMO}

Introdução: O evidente aumento do número de pessoas que escolhem a corrida como forma de exercitar o corpo tem sido associado à maior prevalência de lesões musculoesqueléticas. Objetivos: Verificar a prevalência e os fatores que possam estar associados às lesões em corredores amadores da cidade de Recife-PE. Métodos: Estudo observacional do tipo transversal, no qual 300 corredores amadores responderam a um questionário sociodemográfico, além de questões sobre características do treinamento, tipo de pisada e aterrissagem e histórico de lesões relacionadas à corrida. Os dados foram analisados pela estatística descritiva; para a comparação entre médias, foi usado o Teste $t$ de Student e para a comparação de prevalências, o teste do qui-quadrado. Resultados: A prevalência de lesões em corredores amadores de Recife-PE foi de 58,5\% ( $n=175)$, sendo o joelho a região mais acometida (37,3\%). Nos grupos corredores com lesão e sem lesão, a maioria dos participantes era do sexo masculino, respectivamente, $72,4 \%$ e $72,6 \%$. Não houve diferença quanto à frequência semanal de treinamento entre os grupos $(p<0,63)$. Ao contrário, os corredores com histórico de lesão treinaram em média 7 quilômetros/semana a mais do que os corredores sem lesões $(p<0,03)$. O tipo de pisada neutra ( $F=0,87 ; p=0,99)$ e a aterrissagem com retropé $(F=4,13 ; p=0,90)$ foram os mais referidos pelos corredores em ambos os grupos. Foi verificado que o desgaste foi o principal critério utilizado para trocar de tênis em ambos os grupos ( $F=8,35 ; p=0,4)$. Conclusões: Houve alta prevalência de lesões musculoesqueléticas em corredores amadores de Recife-PE. Entre os fatores associados às lesões, uma variável mostrou-se significante: maior volume de treino semanal. Nível de Evidência: Il; Tipo de Estudo: Transversal.

Descritores: Corrida; Epidemiologia; Lesões.

\section{RESUMEN}

Introducción: El evidente aumento en el número de personas que eligen la carrera como forma de ejercitar el cuerpo ha sido asociado con una mayor prevalencia de lesiones musculoesqueléticas. Objetivos: Verificar la prevalencia y los factores que pueden estar asociados con lesiones en corredores aficionados en la ciudad de Recife-PE. Métodos: Estudio transversal observacional, en el que 300 corredores aficionados respondieron un cuestionario sociodemográfico, además de cuestiones sobre características del entrenamiento, tipo de pisada y aterrizaje e historial de lesiones relacionadas con la carrera. Los datos se analizaron mediante estadística descriptiva; para la comparación entre 
promedios, se utilizó el test t de Studenty para la comparación de prevalencia, la prueba de chi-cuadrado. Resultados: La prevalencia de lesiones en corredores aficionados en Recife-PE fue de 58,5\% ( $n=175)$, siendo la rodilla la región más afectada (37,3\%). En los grupos de corredores lesionados y no lesionados, la mayoría de los participantes eran del sexo masculino, respectivamente, $72,4 \%$ y $72,6 \%$. No hubo diferencias con respecto a la frecuencia de entrenamiento semanal entre los grupos $(p<0,63)$. Por el contrario, los corredores con historial de lesiones entrenaron un promedio de 7 kilómetros/semana más que los corredores sin lesiones $(p<0,03)$. El tipo de pisada neutra $(F=0,87 ; p=0,99)$ yel aterrizaje con retropié ( $F=4,13 ; p=0,90)$ fueron los más indicados por los corredores en ambos grupos. Se encontró que el desgaste fue el principal criterio utilizado para cambiar de zapatillas en ambos grupos ( $F=8,35, p=0,4)$. Conclusiones: Hubo una alta prevalencia de lesiones musculoesqueléticas en corredores aficionados en Recife-PE. Entre los factores asociados con las lesiones, se encontró una variable significativa: el mayor volumen de entrenamiento semanal. Nivel de evidencia Il; Tipo de Estudio: Transversal.

Descriptores: Carrera; Epidemiología; Lesiones.

\section{INTRODUCTION}

Many people who pursue healthy lifestyle habits choose road running as an exercise modality because it is cost-effective and easy to perform ${ }^{1,2}$. With the boost in the number of runners, there has been an increase in the prevalence of running-related musculoskeletal injuries, where the incidence may vary from $19.4 \%$ to $92.4 \%$, depending on the characteristics of the runner studied and the methodology used to assess the occurrence of injury ${ }^{3-5}$.

Gonçalves et al. ${ }^{6}$, in a recent systematic review, found a variation of $29 \%$ to $65 \%$ in the prevalence of running-related injuries in the Brazilian population. When considering the site of injury, the lower limbs stand out, with the knee being the most affected anatomical structure ${ }^{1,6,7}$.

Intrinsic factors such as age, gender, anatomical alignment, and previous injuries; and extrinsic factors related to training characteristics, such as training duration, weekly frequency, average weekly distance, surface type, footwear type, running experience, and the concomitant practice of other sports, influence the onset of musculoskeletal injuries ${ }^{3,5}$.

Among intrinsic factors, the history of previous injuries is more related to the risk of new musculoskeletal injuries, and among extrinsic factors, the average weekly distance ${ }^{7,8}$. It is assumed that training overload can accentuate the symptoms of an overuse injury, causing the runner to change his usual running pattern, overloading integral structures, causing a new injury ${ }^{8}$. Other variables have limited and controversial evidence ${ }^{9-11}$

Thus, there are still divergences about the factors that may influence the occurrence of these diseases, so it is clear the need to deepen the knowledge, aiming at the prevention of injuries and thus the safe performance of training. Moreover, the objective of this study was to verify the prevalence and factors that may be associated with sport injuries in amateur runners in Recife-PE.

\section{MATERIAL AND METHODS}

\section{Study design}

A cross-sectional observational study, guided according to the guidelines of the STROBE (Strengthening the Reporting of Observational Studies in Epidemiology) ${ }^{12}$. The sample involved were 300 amateur runners, who answered a semi-structured questionnaire prepared by the authors, consisting of socio-demographic data, as well as questions about training characteristics, stepping and landing, and history of running-related injuries.

The participants of this research were runners of both sexes, aged between 18 and 65 years old, who have been running for at least 12 months and with a weekly training volume of at least $15 / \mathrm{km}$ per week. Runners with physical disabilities who had performed a surgical procedure on any joint before the start of running and who were unable to answer the questionnaire due to their lack of understanding were excluded. All individuals were informed about the research objectives and those who agreed to participate signed the Free and Informed Consent Form. The study was approved by the Research Ethics Committee of the CCS / UFPE (CAAE: 63572717.0.0000.5208) and complied with Resolution 466/12 of the National Health Council.

The sample size calculation was based on Singer ${ }^{13}$ criteria with a power set at $90 \%$ and $a=0.05$. It was considered the number of runners registered in the main running groups of the city of Recife-PE, at least for twelve months. According to these criteria, the eligible population was 1452 runners. An accuracy of $95 \%$ with a margin of error of $5 \%$ was adopted resulting in a sample size of 300 volunteers.

Individuals were personally invited via email to the representatives of the running groups to which they belonged or to their email addresses. The application of the questionnaire took place at the "Laboratório de Cinesioterapia e Recursos de Terapia Manual- LACIRTEM" (Laboratory of Kinesiotherapy and Manual Therapeutic Resources) and during the road running events that took place in the city of Recife from May to September 2017

The personal variables analyzed were: gender, age, weight and height. The training variables were: running time, weekly frequency, average weekly distance, daily training duration, other sports practice, the presence or abscence of a professional supervision from a running coach, type of landing (first part of the foot that comes in contact with the ground), type of footstep (pronated, supinated and neutral) and criteria used for changing their sport shoes.

In the present study, it was considered an injury any pain or discomfort in the lower limbs that limited or excluded the participation of the runner in training and/or competitions for at least one day ${ }^{5}$. The presence and location of the pain were investigated, as well as the continuity in running training even in the presence of any discomfort resulting from the injury. The above-cited variables were chosen because they are often associated with risk factors for running injury ${ }^{3-5,11 .}$

\section{STATISTICAL ANALYSIS}

SPSS version 23 software was used for data analysis. Variables were tested for data normality using the Shapiro-Wilk test. The values with normal distribution were presented as mean (X) and standard deviation (SD). The significance level for all tests was 5\%. The data were initially presented with descriptive analysis, and for comparison between the groups (with or without a history of injuries) the Student t-test was used. The Chi-square test was used when it was necessary to perform a prevalence comparison. 


\section{RESULTS}

From the sample of 300 runners, one participant answered the questionnaire incompletely, resulting in a final sample of $n=299$ individuals. The prevalence of injuries in amateur runners in Recife-PE was 58.5\% ( $n=175)$. According to the total individuals evaluated, $72 \%(n=216)$ were men and the average age was 38.6 (7.7). Table 1 describes the characteristics of the individuals participating in the study, which was performed a comparative analysis between the group of runners who have already been injured and runners who have never been injured.

Runners with a history of injury had a weekly training frequency similar to those without a history of injury $(p<0.63)$; however, they ranged an average of $7 \mathrm{~km}$ more per week $(p<0.03)$ (Table 2).

Regarding the practice of other sports ( $X 2=0.945 ; p=0.331)$ and professional orientation for running ( $X 2=0.018 ; p=0.897$ ), there was no significant difference between the groups. Among the runners with a history of injuries, 108 (61.7\%) reported practicing other sports, and 109 (62.3\%) had running-oriented professional guidance, while in the group without a history of injuries 69 (55.6\%) practiced other sports and 79 (67.3\%) had a professional orientation.

Neutral footstep ( $F=0.87 ; p=0.99$ ) and the rearfoot landing $(F=4.13 ; p=0.90)$ were the most reported by runners in both groups. The wear was found to be the main criterion used by runners to change their footwear in both groups $(F=8.52 ; p=0.4)$.

According to the number of areas investigated, the knee was the anatomical region most affected (37.3\%) by injuries, regardless of the number of runners, as some of them had more than one injury (Table 4). Finally, it was observed that $61 \%(n=106)$ of runners with a history of injury reported running even with pain.

Table 1. Description of characteristics of Individuals by allocation group

\begin{tabular}{|c|c|c|c|}
\hline Variable & $\begin{array}{l}\text { With a history } \\
\text { of injury } \\
(n=175)\end{array}$ & $\begin{array}{l}\text { No history } \\
\text { of injury } \\
(n=124)\end{array}$ & $\begin{array}{c}\mathrm{p}-\text { Value } \\
\mathrm{Cl}(95 \%) \\
\text { differences between averages }\end{array}$ \\
\hline Sex & n (\%) & n (\%) & \\
\hline Male & $124(70.9)$ & $90(72.6)$ & - \\
\hline Female & $51(29,1)$ & $34(27.4)$ & - \\
\hline Age & $39.18(9.7)$ & $37.74(9.4)$ & $\begin{array}{c}0.20 \\
\mathrm{Cl}(-3.65 \text { to } 0.77)-1.44\end{array}$ \\
\hline Weight & 72.85 (12.8) & $73.22(12.0)$ & $\begin{array}{c}0.80 \\
\text { IC }(-2.53 \text { to } 3.27) 0.37\end{array}$ \\
\hline Height & 169.53 (19.9) & $171.61(7.5)$ & $\begin{array}{c}0.27 \\
\mathrm{Cl}(-1.62 \text { to } 5.78) 2.07\end{array}$ \\
\hline $\begin{array}{l}\text { Training } \\
\text { experience } \\
\text { (months) }\end{array}$ & $79.01(84.3)$ & $71.08(79.4)$ & $\begin{array}{c}0.41 \\
\mathrm{Cl}(-26.95 \text { to } 11.07)-7.93\end{array}$ \\
\hline
\end{tabular}

Variables were presented as mean and standard deviation and t-test Student was performed, except sex represented as absolute and relative frequencies. Cl: confidence interval.

Table 2. Description of training characteristics.

\begin{tabular}{c|c|c|c}
\hline Variable & $\begin{array}{c}\text { With a history of } \\
\text { injury }(\mathbf{n}=175) \\
\mathbf{X}(\mathbf{S D})\end{array}$ & $\begin{array}{c}\text { No history of } \\
\text { injury }(\mathbf{n}=124) \\
\mathbf{X}(\mathbf{S D})\end{array}$ & $\begin{array}{c}\mathbf{p} \text { - Value } \\
\mathbf{C l}(\mathbf{9 5} \%) \\
\text { differences } \\
\text { between averages }\end{array}$ \\
\hline $\begin{array}{c}\text { Weekly frequency } \\
\text { (n\%/wk) }\end{array}$ & $3.49(1.2)$ & $3.41(1.3)$ & $\begin{array}{c}0.63 \\
\mathrm{Cl}(-0.37 \text { to } 0.22) 0.08\end{array}$ \\
\hline $\begin{array}{c}\text { Weekly average } \\
\text { distance (km) }\end{array}$ & $39.78(31.4)$ & $32.57(26.3)$ & $\begin{array}{c}0.03 \\
\mathrm{Cl}(-14.05 \text { to } \\
-0.37) 7.51\end{array}$ \\
\hline $\begin{array}{c}\text { Daily training } \\
\text { duration (min) }\end{array}$ & $67.98(24.4)$ & $63.55(24.4)$ & $\begin{array}{c}0.10 \\
\mathrm{Cl}(-10.08 \text { to } 1.22) 4.43\end{array}$ \\
\hline
\end{tabular}

The data are will express them as mean and standard deviation ( $t$ test for unpaired samples independent , $\mathrm{p}$ $<0.05)$; Cl: confidence interval

Rev Bras Med Esporte - Vol. 26, № 3 - Mai/Jun, 2020
Table 3. Description of the type of footstep, type of landing and criteria for changing shoes

\begin{tabular}{|c|c|c|c|}
\hline Variable & $\begin{array}{c}\text { With a history of } \\
\text { injuries }(n=175) \\
n(\%)\end{array}$ & $\begin{array}{c}\text { No history of } \\
\text { injuries }(n=124) \\
n(\%)\end{array}$ & $p$-Value \\
\hline \multicolumn{3}{|c|}{ Referred Footstep Types } & \multirow{5}{*}{099} \\
\hline Neutral & $57(32.6)$ & $43(44.7)$ & \\
\hline Supine & $33(18.9)$ & $19(15.3)$ & \\
\hline Pronated & $32(18.2)$ & $21(17.0)$ & \\
\hline Do not know & $53(30.3)$ & $41(33.0)$ & \\
\hline \multicolumn{4}{|c|}{ Referred Landing Types } \\
\hline Forefoot & $40(22.9)$ & $31(25.0)$ & \multirow{4}{*}{0,90} \\
\hline Midfoot & $44(25.1)$ & $36(29.0)$ & \\
\hline Rearfoot & $79(45.1)$ & $43(34.7)$ & \\
\hline Do not know & $12(6.9)$ & $14(11.3)$ & \\
\hline \multicolumn{4}{|c|}{ Criteria for changing shoes } \\
\hline Wear & $89(50.9)$ & $69(55.6)$ & \multirow{4}{*}{0.4} \\
\hline Time & $39(22.3)$ & $14(11.3)$ & \\
\hline Mileage & $25(14.3)$ & $28(22.6)$ & \\
\hline Others & $22(12.6)$ & $10(10.5)$ & \\
\hline
\end{tabular}

Data are expressed in number of runners and percentage (chi-square test).

Table 4. Prevalence of the anatomical location of the lesions.

\begin{tabular}{c|c}
\hline Lesion location & $\mathbf{n}(\%)$ \\
\hline Hip & $20(8.3)$ \\
\hline Thigh & $20(8.3)$ \\
\hline knee & $90(37.3)$ \\
\hline Leg & $47(19.5)$ \\
\hline Ankle & $37(15.4)$ \\
\hline Foot & $27(11.2)$ \\
\hline
\end{tabular}

*Values referring to the number of affected areas regardless of the number of corridors

\section{DISCUSSION}

This study aimed to verify the prevalence and possible factors associated with musculoskeletal injuries in amateur runners in Recife-PE. The prevalence of injuries found in this population was 58.5\%. Nevertheless, in the literature, there is a high inconstancy among these results 8 .

In Brazil, Campos et al. ${ }^{14}$ found an injury prevalence of $37 \%$ in a study conducted with 139 runners in the city of Belo Horizonte. This variability continues with the following studies: Hespanhol et al. ${ }^{1}, 55 \%$ with a sample of 200 runners; Abiko et al. ${ }^{15}, 47.5 \%$ in a study conducted with 162 participants; and Purim et al. ${ }^{16}, 65.9 \%$ in a study with 220 regular runners. It is believed that this large percentages range may be justified by the heterogeneity of the samples and the different methods used to evaluate these runners.

There is a meaningful number of difficulties in those investigations on sports injuries due to methodological aspects, such as the definition of the concept of injury ${ }^{7}$. Buist et al. ${ }^{4}$ considered injury any musculoskeletal pain related to running in the lower limbs causing a running restriction for at least one week, in other words, 3 (three) consecutive scheduled training sessions.

Middelkoop et al. ${ }^{2}$ defined as injury a self-reported event in the muscles, joints, tendons and/or bones of the lower extremities, severe enough to cause a reduction in training distance, speed, duration or frequency. For this study, we considered injury any pain or injury in the lower limbs that limited or removed the athlete's participation in training and/or competition for at least one day ${ }^{5}$. Thus, standardization is necessary to compare results and reduce this extensive variations observed in current injury rates.

The largest proportion of practicing amateur runners in this study were male, most individuals were in the $30-40$ age group, representing an average of 38.6 years, and had running experience for more than five 
years, similar to the sample found in other studies that also analyzed runners $1,7,17$, and only one study presented a higher proportion of women 4 .

In the current study, age and time of running were not associated with injuries. This finding is supported by a recent systematic review, in which the authors conclude that there is limited evidence that these variables are critical factors for injuries ${ }^{18}$. In a study of 629 runners with a mean age of 43.7 years, the risk profile differed between genders, with a younger age being associated with a higher risk of injury in male runners, while the lower running experience was associated with the highest risk of injury for both sexes ${ }^{5}$.

Regarding training variables, weekly frequency and daily training duration agree with the literature ${ }^{17-19}$. In the present study, it was evidenced that the group of runners with a history of injury ranged $7 \mathrm{~km}$ more when compared to the group without injuries $(p=0.03)$. Collaborating with other studies that also reported higher weekly long mileage in runners who suffered injuries 78,16 .

Vander Worp et al. ${ }^{18}$, in a systematic review reported that men would have a higher risk of injury over a weekly distance of $32-39 \mathrm{~km}$. In contrast, Saragiotto et al. ${ }^{8}$ stated that they would be more likely to suffer runner injuries that had training volumes greater than 64 kilometers per week. This can be explained by the fact that the higher training volume can increase the stress level on the body and thus contribute to a higher occurrence of injuries ${ }^{6}$.

Regarding the type of footstep, Bennet et al. ${ }^{20}$, in a study evaluating 77 runners, found that individuals with overpronation were more likely to suffer injuries. However, in the present study, there was no difference between the groups regarding the type of footstep, which is consistent with other findings in the literature, in which there is limited evidence that the type of footstep is a critical factor for runner injuries ${ }^{18,21}$.

Rearfoot landing was present in both groups and was not a factor associated with musculoskeletal injuries. Some studies have been performed comparing the landing pattern, with contact with the rearfoot associated with higher impact peak ${ }^{22-24}$.

Lieberman et al.25 state that in the greater part of the human evolution, individuals were running barefoot, which would contribute to initial contact with the forefoot and midfoot and that landing with the rearfoot contributes to greater collision forces during running. We believe that this higher prevalence of initial contact with the rearfoot found in both groups is due to the damping system of modern sneakers that determine a high drop, and consequently, determines this pattern attack (the first part of the foot that reaches the ground) ${ }^{25}$.
It was observed in both groups of runners, with and without an injury history, that the main criterion used to change shoes was the wear throughout use. Some studies have shown that footwear characteristics influence impact forces during running ${ }^{11,25,26}$. Malioux et al. ${ }^{27}$, in a prospective study, reported that worn shoes can lead runners to harmful kinematic adaptations, increasing the risk of musculoskeletal injuries.

Regarding the anatomical location, the knee was the most affected region, as present in several studies in the literature ${ }^{1,17,28,29}$. This high rate of knee injuries is often attributed to the magnitude of impact forces directed at this joint cyclically during running ${ }^{25}$.

The high percentage of runners who even with injuries remain running, in this study (61\%), corroborates the findings of Johansen et a ${ }^{30}$, who when were investigating the attitudes of runners during a competition or even training, observed that the pain was not a factor responsible for the interruption of the practice or development of potential injuries.

As limitations of the study, it is important to emphasize that it was conducted through a self-report survey allowing possible memory bias. Footsteps and landing type variables could not be proven since no physical evaluations were performed. Also, it was observed that less experienced runners were not aware of the type of landing and were confused about the type of footstep performed during the running.

The contributions of this study refer to the clarification regarding the prevalence of musculoskeletal injuries of amateur runners in the city of Recife and the knowledge about the associated factors presented. It is believed that these data may be essential as sources of prospective studies so that it is possible to explore the causal relationships between the variables investigated in this study.

\section{CONCLUSION}

In this study, the prevalence of musculoskeletal injuries in amateur runners in Recife-PE was 58.5\%. Among the factors associated with injuries, it was found that runners with a history of injuries had a higher weekly training volume.

\section{ACKNOWLEDGMENT}

Acknowledgment of the UFPE Institutional Scientific Initiation Scholarship Program - PIBIC / UFPE / CNPq for the scholarship granted.

All authors declare no potential conflict of interest related to this article

AUTHORS' CONTRIBUTIONS: Each author contributed individually and significantly to the development of this article. MEFC: article writing and data acquisition; JBF: data acquisition and data interpretation; AISDO: statistical analysis and article review; KADAC: article writing and data acquisition; MDGRDA: Data Analysis and Review of the Article; APDLF: writing of the article, intellectual concept and preparation of the entire research project.

\section{REFERENCES}

1. Hespanhol Junior LC, Costa LO, Carvalho AC, Lopes AD. Perfil das características do treinamento e associação com lesões musculoesqueléticas prévias em corredores recreacionais: um estudo transversal. Brazilian J Phys Fisiother. 2012;16(1):46-53.

2. van Middelkoop M, Kolkman J, van Ochten J, Bierma-Zeinstra SM, Koes BW. Risk factors for lower extremity injuries among male marathon runners. Scand J Med Sci Sport. 2008;18(6):691-7.

3. van Gent RN, Siem D, van Middeloop M, van Os AG, Bierma-Zeinstra SM, Koes BW. Incidence and determinants of lower extremity running injuries in long distance runners: a systematic review. $\mathrm{Br} J$ Sport Med. 2007;41(8):469-80.

4. Buist I, Bredeweg SW, Lemmink KA, van Mechelen W, Diercks RL. Predictors of running-related injuries in novice runners enrolled in a systematic training program: a prospective cohort study. Am J Sports Med. 2010;38:273-280

5. Buist I, Bredeweg SW, Bessem B, van Mechelen W, Lemmink KA, Diercks RL. Incidence and risk factors of running-related injuries during preparation for a 4-mile recreational running event. Br J Sports Med. 2010;44(8):598-604.

6. Gonçalves D, Sties SW, Andreato LV, Aranha EE, Pedrini L, Oliveira C. Prevalência de lesões em corredores de rua e fatores associados: revisão sistemática. Cinergis. 2016;17(3):235-8.
7. Ferreira AC, Dias JM, Fernandes RM, Sabino GS, Anjos MT, Felício DC. Prevalence and associated risks of injury in amateur street runners from Belo Horizonte, MG. Rev Bras Med Esporte. 2012;18(4):252-5.

8. Saragiotto BT, Yamato TP, Hespanhol Junior LC, Rainbow MJ, Davis IS, Lopes AD. What are the main risk factors for running-related injuries? Sport Med. 2014;44(8):1153-63.

9. Ryan $M$, Elashi $M$, Newsham-West $R$, Taunton J. Examining injury risk and pain perception in runners using minimalist footwear. Br J Sports Med. 2014;48(16):1257-62.

10. Molloy JM. Factors influencing running-related musculoskeletal injury risk among U.S. military recruits. Mil Med. 2016;181(6):512-23.

11. Ridge ST, Standifird T, Rivera J, Johnson AW Mitchell U, Hunter I. The effect of training in minimalist running shoes on running economy. J Sport Sci Med. 2015;14(3):643-7.

12. Maltal M, Cardoso LO, Bastos FI, Magnanini MM, Silva CM. Iniciativa STROBE: subsídios para a comunicação de estudos observacionais. Rev Saude Publica. 2010;44(3):559-65.

13. Singer J. A simple procedure to compute the sample size needed to compare two independent groups when the population variances are unequal. Stat Med. 2001;20(7):1089-95.

14. Campos AC, Prata MS, Aguiar SS, Castro HO, Leite RD, Pires FO. Prevalência de lesões em corredores de rua amadores. Rev Bras Pesq Cienc Saude. 2016;3(1):40-5. 
15. Abiko RH, Tamura SH, Borges PH, Bertolini SM. Prevalência de lesões musculoesqueléticas e fatores associados em corredores de rua. Ciencia Saude. 2017;10(2):109.

16. Purim KS, Kapptitski AC, Bento PC, Leite N. Lesões desportivas e cutâneas em adeptos de corrida de rua. Rev Bras Med Esporte. 2014;20(4):299-303.

17. Rangel GM, Farias JM. Incidência de lesões em praticantes de corrida de rua no município de criciúma, Brasil. Rev Bras Med Esporte. 2016;22(6):496-500.

18. van der Worp MP, ten Haaf DS, van Cingel R, de Wijer A, Nijhuis-van der Sanden MW, Staal JB. Injuries in runners; a systematic review on risk factors and sex differences. PLoS One. 2015;10(2):e0114937.

19. Ishida JC, J, Turi BC, Pereira-da-silva M, Amaral SL. Presença de fatores de risco de doenças cardiovasculares e de lesões em praticantes de corrida de rua. Rev Bras Educ Fís Esporte. 2013;27(1):55-65.

20. Bennett JE, Reinking MF, Rauh MJ. The relationship between isotonic plantar flexor endurance, navicular drop, and exercise-related leg pain in a cohort of collegiate cross-country runners. Int J Sports Phys Ther. 2012; 7(3):267-78.

21. Knapik JJ, Trone DW, Tchandja J, Jones BH. Injury-Reduction Effectiveness of Prescribing Running Shoes on the Basis of Foot Arch Height: Summary of Military Investigations. J Orthop Sport Phys Ther. 2014;44(10):805-12.

22. Hasegawa $\mathrm{H}$, Yamauchi T, Kraemer WJ. Foot strike patterns of runners at the $15-\mathrm{km}$ point during an elite-level half marathon. J Strength Cond Res. 2007;21(3):888-93.
23. Goss DL, Gross MT. Relationships among self-reported shoe type, footstrike pattern, and injury incidence. US Army Med Dep J. 2012;25-30

24. Squadrone R. Biomechanical and physiological comparison of barefoot and two shod conditions in experienced barefoot runners. J Sport Med Phys Fitness. 2009;49(1):6-13.

25. Lieberman DE, Venkadesan M, Werbel WA, Daoud Al, D'Andrea S, Davis IS, et al. Foot strike patterns and collision forces in habitually barefoot versus shod runners. Nature. 2010;463(7280):531-5.

26. Nigg BM, Baltich J, Maurer C, Federolf P. Shoe midsole hardness, sex and age effects on lower extremity kinematics during running. J Biomech. 2012;45(9):1692-7.

27. Malisoux L, Ramesh J, Mann R, Seil R, Urhausen A, Theisen D. Can parallel use of different running shoes decrease running-related injury risk? Scand J Med Sci Sports. 2015;25(1):110-5.

28. Araujo MK, Baeza RM, Ricardo S, Zalada SR, Alves PB, Mattos CA. Lesões em praticantes amadores de corrida. Rev Bras Ortop. 2015;50(5):537-40.

29. Powers CM. The influence of abnormal hip mechanics on knee injury: a biomechanical perspective. J Orthop Sport Phys Ther. 2010;40(2):42-51.

30. ohansen KK, Hulme A, Damsted C, Ramskov D, Nielsen RO. Running injury development the attitudes of middle- and long-distance runners and their coaches. Int J Sports Phys Ther. 2017;12(4):634-41 